\title{
An Anatomical Study of Variations of Sacral Hiatus in Sacra of North Indian Origin and Its Clinical Significance
}

\author{
Estudio Anatómico de las Variaciones del Hiato Sacro \\ en Sacros del Norte de la India y su Significancia Clínica
}

Seema*; Singh, M.** \& Mahajan, A.***

SEEMA; SINGH, M. \& MAHAJAN, A. An anatomical study of variations of sacral hiatus in sacra of north indian origin and its clinical significance. Int. J. Morphol., 31(1):110-114, 2013.

SUMMARY: Sacrum is formed by the fusion of five sacral vertebrae and forms the lower part of vertebral column. The opening present at the lower end of sacral canal is known as sacral hiatus. Anatomical variations in morphology and morphometry of sacral hiatus are important clinically as well as surgically. 159 dry clean human Sacra were taken from Department of Anatomy, Sri Guru Ram Das Institute of Medical Sciences and Research Vallah (Amritsar). Various shapes of sacral hiatus were observed which included inverted U $(42.95 \%)$, inverted V $(27.51 \%)$, irregular $(16.10 \%)$, dumbbell $(11.40 \%)$ and bifid $(2.01 \%)$. The apex of sacral hiatus was commonly found at the level of 4 th sacral vertebra in $56.36 \%$. The mean length of sacral hiatus was $22.69 \mathrm{~mm}$. The mean anteroposterior diameter of sacral canal at the apex of sacral hiatus was $6.49 \mathrm{~mm}$. Narrowing of sacral canal at the apex of sacral hiatus (diameter less than $3 \mathrm{~mm}$ ) was observed to be high (5.36\%). The knowledge of anatomical variations of dimensions of sacral hiatus is important while doing caudal epidural block and it may help to improve its success rate.

KEY WORDS: Sacral Hiatus; Apex; Sacral canal; Caudal epidural block.

\section{INTRODUCTION}

The sacrum is a large triangular bone present between the two innominate bones forming posterosuperior wall of pelvic cavity (Soames, 2008). The opening present at the caudal end of sacral canal is known as sacral hiatus. It is formed due to the failure of fusion of laminae of the fifth (occasionally $4^{\text {th }}$ ) sacral vertebra. It is located inferior to the $4^{\text {th }}\left(\right.$ or $\left.3^{\text {rd }}\right)$ fused sacral spines or lower end of median sacral crest. On the body surface the hiatus can be marked two inches above the tip of coccyx beneath the skin of natal cleft (Soames; Moore \& Dalley, 1995). The hiatus is covered posteriorly by skin, a subcutaneous fatty layer and the sacrococcygeal membrane (Sekiguchi et al., 2004). When the needle has passed through sacrococcygeal ligament the hiatus communicates with the epidural space. The dural sac ends at the level of the second piece of the sacrum. The sacral canal below this level contains extradural fat, vertebral venous plexus, lower sacral nerve roots and the filum terminale (Soames; Waldman, 2004; Ellis, 2006). Sacral hiatus has been utilized for administration of epidural anaesthesia in obstetrics (Edward \& Hingson, 1942) as well as in orthopaedic practice for transpedicular and lateral mass screw placement (Sekiguchi). The reliability and success of caudal epidural anaesthesia depends upon anatomical variations of sacral hiatus as observed by various authors (Sekiguchi; Trotter \& Lanier, 1945; Trotter, 1947; Kumar et al., 1992; Chen et al., 2004; Aggarwal et al., 2009). Even the caloscopy is successful if we know the common possible variations in the morphology and morphometry of the sacral hiatus (Mourgela et al., 2009). The variation in the development of the sacral hiatus can cause decrease area for the attachment of extensor muscle at back causing painful conditions (Brailsford, 1929). Sacral hiatus with guide wire assistance is an accessible conduit for uncomplicated entry into the subarachnoid and basal cisternal space without damaging the surrounding structures (Layer et al., 2011). The present study was undertaken to find out the anatomical variations of the sacral hiatus in North Indians in the form of shape, length and breadth and antero posterior diameter.

\footnotetext{
* Associate Professor, Department of Anatomy, Sri Guru Ram Das Institute of Medical Sciences and Research Vallah, Amritsar, India.

*** ESI Hospital, Amritsar, India.

****Professor and Head, Department of Anatomy, Sri Guru Ram Das Institute of Medical Sciences and Research Vallah, Amritsar, India.
} 


\section{MATERIAL AND METHOD}

The present study was conducted on 159 dry human sacra collected from Department of Anatomy, Sri Guru Ram Das Institute of Medical Sciences and Research, Vallah (Amritsar). Each sacrum was studied for different features of sacral hiatus with regards to:

- Shape of hiatus

- Level of apex of hiatus

- Level of base of hiatus

- Length of hiatus- measured from apex to midpoint of the base

- Anteroposterior diameter of sacral hiatus at the apex

- Transverse width of sacral hiatus at the base.

- Distance between the apex of the sacral hiatus and second sacral spinous process

The measurements were taken with the help of vernier caliper.

\section{RESULTS}

In five sacra, there was complete agenesis of the dorsal bony wall of the sacral canal $(3.14 \%)$. In four sacra the sacral hiatus was absent $(2.51 \%)$. In one sacral hiatus was $<6 \mathrm{~mm}(0.062 \%)$. These ten sacra were excluded from the measurements as typical sacral hiatus was not present in them. Most common shape of the sacral hiatus was inverted

Table I. Shape of sacral hiatus $(n=149)$.

\begin{tabular}{llcc}
\hline S n & Shape & n & Percentage \\
\hline 1 & Inverted U & 64 & 42.95 \\
2 & Inverted V & 41 & 27.51 \\
3 & Irregular & 24 & 16.10 \\
4 & Dumbbell & 20 & 13.41 \\
\hline
\end{tabular}

Table III. Length of sacral hiatus from apex to midpoint of base $(n=149)$.

\begin{tabular}{lccc}
\hline S n & Length $(\mathbf{m m})$ & n & Percentage \\
\hline 1 & $0-10$ & 17 & 11.409 \\
2 & $11-20$ & 52 & 34.899 \\
3 & $21-30$ & 44 & 29.53 \\
4 & $31-40$ & 25 & 16.778 \\
5 & $41-50$ & 7 & 4.697 \\
6 & $>51$ & 4 & 2.684 \\
\hline
\end{tabular}

Table IV. Anteroposterior Diameter of Sacral Canal at the level of apex $(n=149)$.

\begin{tabular}{lccc}
\hline S n & Diame ter $(\mathbf{m m})$ & n & Percentage \\
\hline 1 & $0-3$ & 8 & 5.36 \\
2 & $4-6$ & 107 & 71.81 \\
3 & $7-9$ & 33 & 22.147 \\
4 & $>9$ & 1 & 0.671 \\
\hline
\end{tabular}

Table V. Distance between the Sacral Cornua at the base of Sacral Hiatus $(n=149)$.

\begin{tabular}{lccc}
\hline S n & Distance $(\mathbf{m m})$ & $\mathbf{n}$ & Percentage \\
\hline 1 & $0-5$ & 14 & 9.395 \\
2 & $6-10$ & 45 & 30.20 \\
3 & $11-15$ & 77 & 51.677 \\
4 & $>16$ & 13 & 8.72 \\
\hline
\end{tabular}

U (42.95\%) (Table I). Apex and base were most commonly observed at fourth and fifth sacral spines respectively (Table II). Height/length and anteroposterior depth at the apex of hiatus were ranged $11-20 \mathrm{~mm}(34.89 \%)$ and $4-6 \mathrm{~mm}(71.81 \%)$ respectively (Tables III and IV). Mean intercornual distance at the base was $11-15 \mathrm{~mm}(51.677 \%)$ (Table V). Minimum distance between the second sacral vertebra and the apex was $7.1 \mathrm{~mm}$. Depth of the hiatus at the apex less than $3 \mathrm{~mm}$ was in $5.36 \%$ of cases.

Table II. Location of Apex and base in relation to the level of sacral vertebrae $(n=149)$.

\begin{tabular}{llcccc}
\hline \multirow{2}{*}{ S n } & \multirow{2}{*}{ Vertebral level } & \multicolumn{2}{c}{ Location of A pex } & \multicolumn{2}{c}{ Location of Base } \\
\cline { 3 - 6 } & & n & Percentage & n & Percentage \\
\hline 1 & $5^{\text {th }}$ sacral vertebra & 6 & 4.02 & 105 & 70.46 \\
2 & $4^{\text {th }}$ sacral vertebra & 84 & 56.36 & 20 & 13.42 \\
3 & $3^{\text {rd }}$ acral vertebra & 53 & 35.57 & - & - \\
4 & $2^{\text {nd }}$ Sacral vertebra & 6 & 4.02 & - & - \\
5 & Coccyx & - & - & 24 & 16.10 \\
\hline
\end{tabular}




\section{DISCUSSION}

Clinically the study on the variations of sacral hiatus can help to identify the caudal epidural space in giving caudal epidural block by palpating the sacral cornu (Chen et al.). Ultrasonography of fluoroscopy is $100 \%$ successful in caudal epidural block but it is not always possible due to time, cost and personal availability. So knowing the anatomical relations of the sacral hiatus will facilitate the procedure (Stitz \& Sommer, 1999).

Shape. Kumar et al., (2009) noted various shapes of sacral hiatus, most common being inverted V (76.23\%), and inverted $U$ in $27.51 \%$, in $7.43 \%$ were dumbbell shaped. In the present study also the shapes of sacral hiatus were variable, most common inverted $\mathrm{U}(42.95 \%)$ as also given by Aggarwal et al., (40.35\%) (Fig. 1A, Table VI). In $13.41 \%$ its outline was like a dumbbell (Fig. 1C) while in $16.11 \%$ it was irregular (Fig. 1D).

There was complete agenesis of dorsal bony wall of

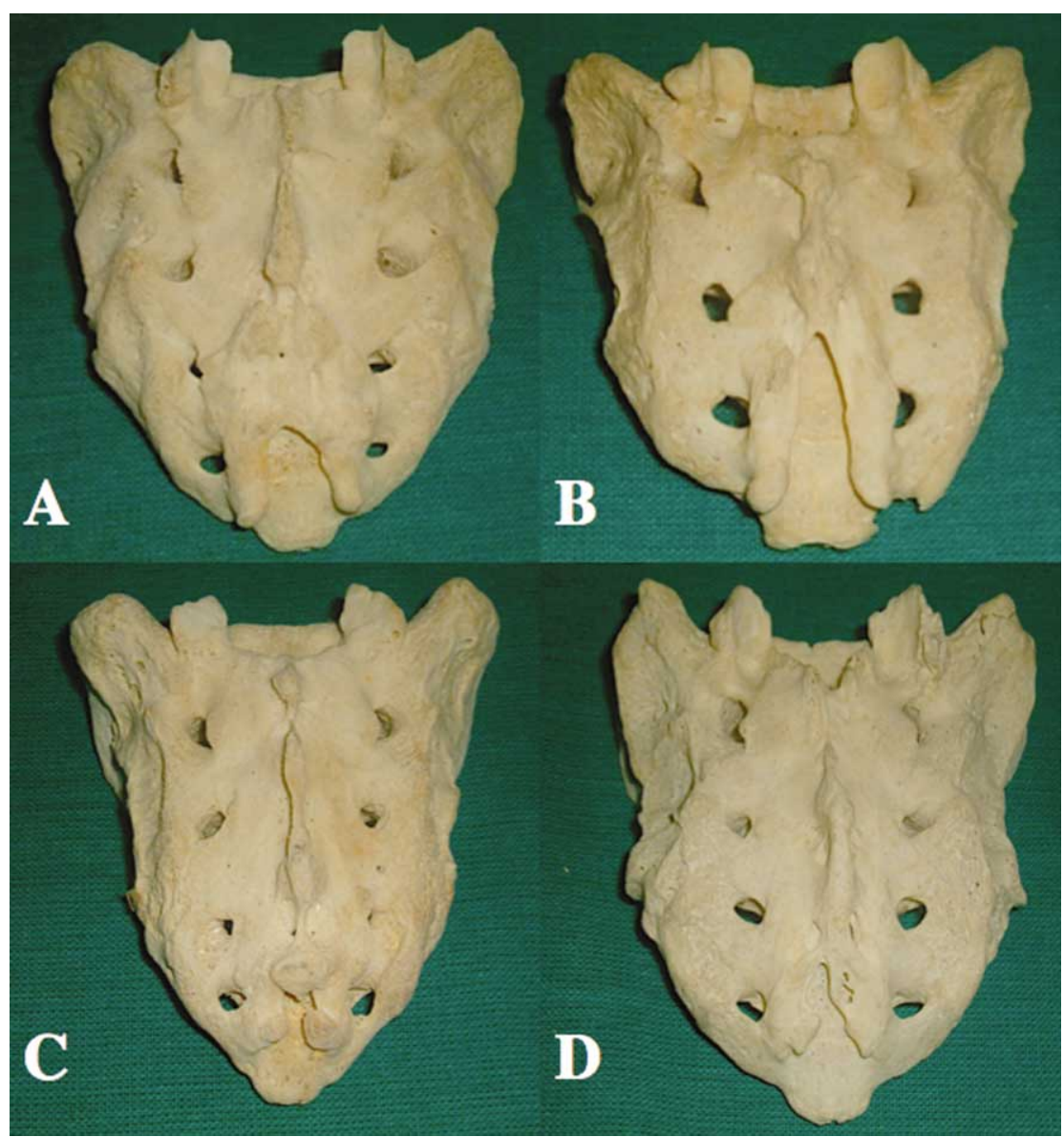

Fig. 1. Shape of sacral hiatus. A) Inverted U shaped. B) Inverted V shaped. C) Dumbbell shaped, and D) Irregular shaped. sacral canal in $3.14 \%$ sacra of the present study. This is similar to that reported by previous workers namely $11.8 \%$ by Trotter et al., $1.49 \%$ by Kumar et al., (2009) and $1.5 \%$ by Nagar (2004). In $1.33 \%$ of sacra in present study, the hiatus was absent due to bony overgrowth which is similar to that reported by Kumar et al., (2009) gave it as $0.99 \%$ whereas in a study by Sekiguchi et al., it was absent in $3 \%$ cases. The patients with low backache in one study showed higher percentage of deficient dorsal wall (Kumar et al., 2009).

Apex of hiatus. In the present study the apex of sacral hiatus was seen most commonly $(56.67 \%)$ at the level of 4 th vertebra (Table I) as given by standard textbooks of Anatomy. Kumar et al., (2009) found level of apex at S4 in $76.23 \%$ and Sekiguchi et al., in $64 \%$ cases. Earlier studies (Trotter; Trotter \& Letterman, 1944; Lanier et al., 1944) in their series have reported the mean level of hiatus to be at lower third of 4th sacral vertebra. All studies including the present noted that location of apex can vary from upper end of S2 to lower part of S5. Distance from the apex of the sacral hiatus to the lower lumbar spinous processes is important to develop the techniques to prevent the neurological injury associated with the neuraxial injections (Duncan et al., 2009).

Base. The base of sacral hiatus was seen at level of S5 vertebra in $71.67 \%$ sacra (Table II), similar to Kumar et al., (2009) (81.17\%) and Aggarwal et al.

Length. The length of hiatus in about $2 / 3 \mathrm{rd}$ of sacra $(65 \%)$ was $11-30 \mathrm{~mm}$ in the present study (Table III). Kumar et al., (2009) observed mean length of hiatus as $20 \mathrm{~mm}$ in males and $18.9 \%$ in females. Trotter \& Lanier have reported hiatal length as $24.8 \mathrm{~mm}$ in American males and $19.8 \mathrm{~mm}$ in females. Similar results were noted by earlier studies of Trotter \& Letterman in which the length of hiatus varied from 0-60 mm with a mean of $22.5 \mathrm{~mm}$ and Lanier et al. showed mean length of hiatus being $25.3 \mathrm{~mm}$. 
Table VI. Comparison between the findings of different authors in different regions.

\begin{tabular}{|c|c|c|c|c|c|c|c|}
\hline Author & Year & Shape & $\begin{array}{c}\text { Level of } \\
\text { Apex }\end{array}$ & $\begin{array}{c}\text { Level of } \\
\text { B ase }\end{array}$ & Length & $\begin{array}{c}\text { Anteroposterior } \\
\text { diameter at the apex }\end{array}$ & Base \\
\hline Nagar et al. & 2004 & Inverted U (41.51\%) & S4 & S5 & $11-20 \mathrm{~mm}$ & $4-6 \mathrm{~mm}$ & $10-15 \mathrm{~mm}$ \\
\hline Aggarwal et al. & 2009 & Inverted U (40.35\%) & $\mathrm{S} 4$ & & $4.30-38.60 \mathrm{~mm}$ & $1.90-10.40 \mathrm{~mm}$ & $11.95+2.78 \mathrm{~mm}$ \\
\hline Njihia et al. & 2011 & Inverted V (32.1\%) & $\mathrm{S} 4$ & -- & -- & $6.4=3.1 \mathrm{~mm}$ & -- \\
\hline Present study & 2013 & Inverted U (42.95) & $\mathrm{S} 4$ & S5 & $11-20 \mathrm{~mm}$ & 4-6 mm & $11-15 \mathrm{~mm}$ \\
\hline
\end{tabular}

Anteroposterior diameter at apex. The anteroposterior diameter of sacral canal at apex of sacral hiatus is important as it should be sufficiently large to admit a needle. Varying diameters lead to subcutaneous deposition of anaesthetic drug. In the present study the anteroposterior diameter ranged from 2 to $14 \mathrm{~mm}$ with a mean of $4.70 \mathrm{~mm}$ (Table IV). Mean diameters reported by various workers were similar; Trotter \& \& Letterman a range of $0-11 \mathrm{~mm}$ (5.3 mm), Lanier et al., showed 6.1 $\pm 0.2 \mathrm{~mm}$, Trotter \& Lanier showed $5 \mathrm{~mm}$ in Whites and $6 \mathrm{~mm}$ in Negroes group, Kumar et al.,

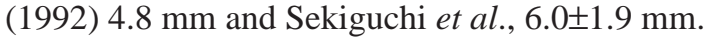

In the present series, sacra had anteroposterior diameter of sacral canal at apex of less than $3 \mathrm{~mm}(5.36 \%)$ which is higher than that of earlier studies namely Trotter \& Letterman who report 5\% cases with 0-2 mm diameter and $4 \%$ sacra with diameter 0-2 mm, while Lanier et al., noted no case with diameter less than $3 \mathrm{~mm}$. It was comparable to the finding of Aggarwal et al., as $8.77 \%$ and Patel et al. (2011).

Width at the base. The width at base of sacral hiatus varied from 0.3 to $18 \mathrm{~mm}$. In more than half $(52 \%)$ cases, it was 11-15 mm. This was almost similar to earlier studies like Trotter \& Letterman who noted the width at base to vary from 7-26 $\mathrm{mm}$ with mean of $17 \mathrm{~mm}$, Lanier et al., who reported mean width at base to be $19.3 \pm 0.3 \mathrm{~mm}$ and Kumar et al., (2009) who reported 5-20 mm (1.3 in mean) and 8$18 \mathrm{~mm}$ (1.25 mm mean) in male and female sacra of his series. Aggarwal et al., gave it as $11.95+2.78 \mathrm{~mm}$ (Table VI). Sekiguchi et al., have reported a lower figure of $10.2 \pm 0.35 \mathrm{~mm}$. however this may be because they noted the average distance between sacral cornuae.

An important point in CEB is awareness of the distance between the sacral hiatus and dural sac anatomically in relation to the risk of dural puncture (Senoglu et al., 2005). Minimum distance between S2 and apex was $7.06 \mathrm{~mm}$ which was comparable to the study by Aggarwal et al., $(7.25 \mathrm{~mm})$ which suggested that it would not be safe to push the needle beyond $7 \mathrm{~mm}$ into sacral canal so as to avoid dural puncture.

\section{CONCLUSION}

The sacral hiatus has anatomical variations and understanding of these variations may improve the success of caudal epidural anesthesia. In the present study, elongated hiatus and narrowing of the sacral canal at apex of sacral hiatus was found in a higher percentage than reported by other authors which should be kept in mind while giving caudal anesthesia in Indian population.

SEEMA; SINGH, M. \& MAHAJAN, A. Estudio anatómico de las variaciones del hiato sacro en sacros del norte de la India y su significancia clínica. Int. J. Morphol., 31(1):110-114, 2013.

RESUMEN: El sacro está conformado por la fusión de las cinco vértebras sacras, y forma la parte inferior de la columna vertebral. La abertura presente en el extremo inferior del canal sacro se conoce como hiato sacro. Las variaciones anatómicas en la morfología y la morfometría del hiato sacro son importantes clínica y quirúrgicamente. Fueron utilizados 159 sacros humanos, limpios y secos, del Departamento de Anatomía, Sri Guru Ram Das Instituto de Ciencias Médicas e Investigación Vallah (Amritsar). Fueron observadas varias formas de hiato sacro: U invertida (42,95\%), V invertida (27,51\%), irregular (16,10\%), de pesa (11,40\%) y bífida $(2,01 \%)$. El ápice del hiato sacro se encuentra comúnmente a nivel de la cuarta vértebra sacra en el 56,36\%. La longitud media de hiato sacro fue 22,69 mm. El diámetro medio anteroposterior del canal sacro en el ápice del hiato sacro fue 6,49 mm. El estrechamiento del canal sacro en el ápice del hiato sacro (diámetro inferior a $3 \mathrm{~mm}$ ) fue alto $(5,36 \%)$. El conocimiento de las variaciones anatómicas de las dimensiones del hiato sacro es importante para el bloqueo epidural caudal y puede ayudar a mejorar su tasa de éxito.

PALABRAS CLAVE: Hiato sacro; Ápice; Canal sacro; Bloqueo epidural caudal. 


\section{REFERENCES}

Aggarwal, A.; Aggarwal, A.; Harjeet \& Sahni, D. Morphometry of sacral hiatus and its clinical relevance in caudal epidural block. Surg. Radiol. Anat., 31(10):793-800, 2009.

Brailsford, J. F. Deformities of lumbosacral region of spine. $\mathrm{Br} . \mathrm{J}$. Surg., 16(64):562-627, 1929.

Chen, P. C.; Tang, S. F.; Hsu, T. C.; Tsai, W. C.; Liu, H. P.; Chen, M. J.; et al., Ultrasound guidance in caudal epidural needle placement. Anesthesiology, 101(1):181-4, 2004.

Duncan, M. A.; Sherriff, M.; O'Keeffe, D. \& Dangerfield, P. H. A radiographic assessment of the distances from the sacral hiatus to the lower lumbar spinous processes. Eur. J. Anat., 13(10):1922, 2009.

Edward, W. B. \& Hingson, R. A. Continuous caudal anesthesia in obstetrics. Am. J. Surg., 57:459-64, 1942.

Ellis, H. The sacrum and the caudal block. Anaesth. Intensive Care Med., 7(11):397-98, 2006.

Kumar, V.; Nayak, S. R.; Potu, B. K. \& Pulakunta, T. Sacral hiatus in relation to low back ache in south Indian population. Bratisk. Lek. Listv., 110(7):436-41, 2009.

Kumar, V.; Pandey, S. N.; Bajpai, R. N.; Jain, P. N. \& Longia, G. S. Morphometrical study of sacral hiatus. J. Anat. Soc. India, 41(1):7-13, 1992.

Lanier, V. S.; Mcknight, H. E. \& Trotter, M. Caudal analgesia: An experimental and anatomical study. Am. J. Obstet. Gynecol., 47(5):633-41, 1944.

Layer, L.; Riascos, R.; Firuzbakht, F.; Amole, A.; VonRitschl, R.; Dipatre, P. \& Cuellar, H, Subarachnoid and Basal Cistern navigation through the sacral hiatus with guidewire assistance. Neurol. Res., 33(6):633-7, 2011.

Moore, K. L. \& Dalley, A. F. Clinically oriented Anatomy. New York, Lippincott Williams \& Wilkins, 1995.

Mourgela, S.; Sakellaropoulos, A.; Anagnostopoulou, S. \& Warnke, J. The dimensions of the sacral spinal canal in the caloscopy: a morphometric MRI study. Neuroanat., 8:1-3, 2009.

Nagar, S. K. A study of sacral hiatus in dry human sacra. J. Anat. Soc. India, 53(2):18-21, 2004.

Njihia, B. N.; Awori, K. O. \& Gikenye, G. Morphology of the sacral hiatus in an African Population-Implications for Caudal Epidural Injections. Ann. Afr. Surg., 7:20-3, 2011.

Patel, Z. K.; Thummar, B.; Rathod, S. P.; Singel, T. C.; Patel, S. \& Zalawadia, A. Multicentric Morphometric Study of Dry Human
Sacrum Of Indian Population In Gujarat Region. NJIRM, 2(2):31-5, 2011.

Sekiguchi, M.; Yabuki, S.; Satoh, K. \& Kikuchi, S. An anatomical study of the sacral hiatus: a basis for successful caudal epidural block. Clin. J. Pain, 20(1):51-4, 2004.

Senoglu, N.; Senoglu, M.; Oksuz, H.; Gumusalan, Y.; Yuksel, K. Z.; Zencirci, B.; et al. Landmarks of the sacral hiatus for caudal epidural block: an anatomical study. Br. J. Anaesth., 95(5):692-5, 2005.

Stitz, M. Y. \& Sommer, H. M. Accuracy of blind versus fluoroscopically guided caudal epidural injection. Spine, 24(13):1371-6, 1999.

Soames, R. W. Skeletal system. In: Williams, P. L.; Bannister, L. H.; Berry, M. M. (Eds.). Gray's Anatomy. 40th Ed. New York, Edinburgh Churchill Livingstone, 2008. pp.528-31, 1430-31.

Trotter, M. Variations of the sacral canal; their significance in the administration of caudal analgesia. Curr. Res. Anesth. Analg., 26(5):192-202, 1947.

Trotter, M. \& Lanier, P. F. Hiatus canalis sacralis in American whites and Negroes. Hum. Biol., 17:368-81, 1945.

Trotter, M. \& Letterman, G. S. Variations of the female sacrum; their significance in continuous caudal analgesia. Surg. Gynaecol. Obstet., 78(4):419-24, 1944.

Waldman, S. D. Caudal epidural nerve block: prone position. In: Atlas of Interventional Pain Management. ${ }^{\text {nd }}$ Ed. Philadelphia, Saunders, 2004. pp.380-92.

\section{Correspondence to:}

Dr. Seema

Associate Professor, Department of Anatomy

Sri Guru Ram Das Institute of Medical Sciences and Research

HNo 2209L4 Kotsaligram, Main Toot Sahib Bazaar

Opposite Gurpreet Tent House

Sultanwind Road, Amritsar

INDIA

Phone 9914754354

Email: drseema16@gmail.com

Received: 04-06-2012

Accepted: 31-10-2012 